[Radiocarbon, Vol. 13, No. 1, 1971, P. 74-77]

\title{
RADIOCARBON, LTD. NATURAL RADIOCARBON MEASUREMENTS I
}

\author{
CHARLES S. TUCEK
}

Radiocarbon, Ltd., Spring Valley, New York

Radiocarbon, Ltd. is a privately owned laboratory designed to provide quality service to the archaeologic and geologic communities. Operations began in 1969 using standard techniques for preparation, conversion to $\mathrm{CO}_{2}$, and purification of samples prior to counting. A sample is counted as $\mathrm{CO}_{2}$ in each of two identical proportional counters of volume 2.2 L, built on the design of östlund and Engstrand (1963); each counter has its own multi-anode guard ring, and is housed in a common shield of iron 8 in. thick.

$\mathrm{CO}_{2}$ from anthracite is used to monitor the background count rate, and the NBS oxalic acid standard is used $\left(0.95 \mathrm{~A}_{\mathrm{ox}}\right)$ as the contemporary count rate reference. Statistical counting variations are quoted to one sigma standard deviation, and the radiocarbon age is based on the $\mathrm{C}^{14}$ half-life of $5570 \pm 30 \mathrm{yr}$.

\section{ACKNOWLEDGMENTS}

I would like to thank Wallace S. Broecker of the Lamont-Doherty Geological Observatory and Paul E. Damon of the University of Arizona for supplying interlaboratory check samples, and for giving timely encouragement. L-607-B, reported as 11,790 \pm 100 (Broecker and Farrand, 1963) was dated at $11,560 \pm 260$ (RL-10); and A-773, reported as $5010 \pm$ 60 (Damon, written commun.) was dated at $4990 \pm 150$ (RL-12).

\section{SAMPLE DESCRIPTIONS}

I. ARGHAEOLOGIC SAMPLES

A. Western United States

\section{Lincoln County (Site 26LN126) series, Nevada}

Charcoal and charred wood samples from Site $26 \mathrm{LN} 126\left(37^{\circ} 30^{\prime}\right.$ $\mathrm{N}$ Lat, $114^{\circ} 30^{\prime} \mathrm{W}$ Long), $5 \mathrm{mi} \mathrm{S}$ of Caliente, Nevada. Coll. 1969 and subm. by D. D. Fowler, Desert Research Inst., Univ. of Nevada, Reno.

\section{RL-36. 26LN126, FS-6}

$230 \pm 100$

Charcoal from hearth in Level I, depth $50 \mathrm{~cm}$. Comment (D.D.F.): stratum from which sample was taken contained Shoshonean ceramics and Desert Side-Notched points.

RL-37. 26LN126, FS-64

$1050 \pm 100$

Charred wood from hearth in Level II, depth $1.35 \mathrm{~m}$. Comment (D.D.F.): sample assoc. with Fremont ceramics. 
RL-38. 26LN126, FS-91

A.D. 1010

$940 \pm 100$

Charcoal from hearth area in Level III, depth $2.5 \mathrm{~m}$. Comment (D.D.F.): sample assoc. with Fremont ceramics.

RL-39. 26LN126, FS-155

$2050 \pm 110$

100 B.C.

Charcoal from hearth area in Level IV, depth $3.0 \mathrm{~m}$. Comment (D.D.F.): sample assoc. with late Desert Archaic points.

RL-40. 26LN126, FS-154

$2090 \pm 100$

140 B.C.

Charcoal from hearth area in Level $\mathrm{V}$, depth $3.5 \mathrm{~m}$. Comment (D.D.F.): sample assoc. with Elko series Desert Archaic point types.

RL-41. 26LN126, FS-163

$1980 \pm 110$

30 B.C.

Charcoal from hearth area in Level $\mathrm{V}$, depth $3.5 \mathrm{~m}$. Comment same comment as for RL-40, for which this sample appears to be a duplicate.

\section{RL-47. Lincoln County (Site 26LN407), Nevada A.D. 980}

$970 \pm 120$

Charcoal from midden deposit, depth $70 \mathrm{~cm}$, at Site 26LN407 $\left(37^{\circ}\right.$ $34^{\prime} \mathrm{N}$ Lat, $114^{\circ} 33^{\prime} \mathrm{W}$ Long), 22 mi ENE of Caliente, Nevada (Sample FS-57). Coll. 1969 and subm. by D. D. Fowler. Comment (D.D.F.): sample from open site at $7000 \mathrm{ft}$ elev. assoc. with Fremont ceramics.

\section{B. Eastern United States}

\section{RL-32. Bluffton-1, Florida}

$3660 \pm 110$

1710 B.c.

Celt (strombus gigas) (made from lip of shell) from Bluffton site on St. Johns R., Florida ( $20^{\circ} 5^{\prime} 0^{\prime \prime} \mathrm{N}$ Lat, $81^{\circ} 30^{\prime} 2^{\prime \prime} \mathrm{W}$ Long), in bottom of fiber-tempered ceramic zone in $14 \mathrm{ft}$ sec. Coll. 1955 and subm. by R. P. Bullen, Florida State Mus., Gainesville. Comment (R.P.B.): should date beginning of plain fiber-tempered ceramic period of Florida, earliest phase of the Orange period. Date is earliest demonstrably assoc. ceramic date for Florida (Bullen, 1958).

\section{West Indies}

RL-26. Lavoutte-1, St. Lucia

A.D. 1240

$710 \pm 100$

Shell (strombus gigas) from shore of Anse Lavoutte at extreme NE side of St. Lucia, Windward Is. (Lesser Antilles) (14 $24^{\prime} 0^{\prime \prime} \mathrm{N}$ Lat, $60^{\circ}$ $55^{\prime} 30^{\prime \prime} \mathrm{W}$ Long), in buried Amerindian shell midden ca. 8 in. thick. Coll. 1968 and subm. by R. P. Bullen. Comment (R.P.B.): dates Suazey ceramic complex and Cap Estate figurine; Suazey is latest known preColumbian complex of Lesser Antilles (Bullen and Bullen, 1970). 


\section{RL-27. Banana Bay-1, Baliceaux Island}

Shell (strombus gigas) from Banana Bay on W side of Baliceaux I.,

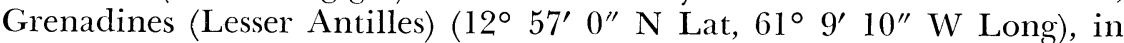
buried Amerindian midden, 8 to 10 in. thick. Coll. 1969 and subm. by R. P. Bullen. Comment (R.P.B.): dates Suazey ceramic complex, proves midden not that of Black Caribs coll. at Baliceaux by British in 1797 before they were taken to Honduras; checks RL-26 with similar ceramic complex.

\section{RL-28. Kingstown Post Office-1, St. Vincent}

$1790 \pm 100$

Shell (strombus gigas) from behind Kingstown post office on St. Vincent, Windward Is. (Lesser Antilles) (13 $3^{\circ} 9^{\prime} 10^{\prime \prime} \mathrm{N}$ Lat, $61^{\circ} 13^{\prime} 35^{\prime \prime}$ W Long), in midden deposit buried by volcanic ash, assoc. with Saladoidlike pottery. Coll. 1969 by Earle Kirby, Dept. of Agric., St. Vincent and subm. by R. P. Bullen. Comment (R.P.B.): dates early phase of Lesser Antillean Modified Saladoid period. As this is not the earliest ceramic complex, it implies pottery was introduced into Lesser Antilles well before instead of ca. time of Christ.

\section{RL-29. Sabazan-1, Carriacou Island}

$$
940 \pm 100
$$

Charcoal from Sabazan Amerindian site at extreme E end of Great Breteche Bay ( $\mathrm{E}$ of Breteche) on $\mathrm{S}$ shore of Carriacou I., Grenadines

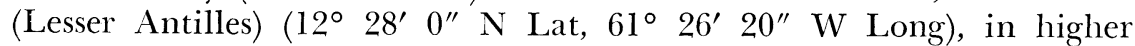
level of a 3 to $4 \mathrm{ft}$ thick stratigraphic sec. exposed by ocean erosion. Coll. 1969 and subm. by R. P. Bullen. Comment (R.P.B.): dates Terminal Saladoid pottery of Lesser Antilles; is a pre-Suazey complex date but may apply to Calviny complex intermediate between Terminal Saladoid (of the Lesser Antilles) and Suazey complexes.

General Comment (R.P.B.): data regarding RL-27-29 will be published in Wm. L. Bryant Foundation, Am. Studies, no. 8 (ms. in preparation).

\section{Giraudy series, St. Lucia}

Shells from Giraudy site at $\mathrm{N}$ side of Beane Field in $\mathrm{S}$ St. Lucia, Windward Is. (Lesser Antilles) (13 $44^{\prime} 0^{\prime \prime} \mathrm{N}$ Lat, $60^{\circ} 56^{\prime} 30^{\prime \prime} \mathrm{W}$ Long). Coll. 1969 by A. K. Bullen and R. P. Bullen, Florida State Mus., and Eric Branford, St. Lucia Archaeol. and Hist. Soc.; subm. by R. P. Bullen.

\section{RL-30. Giraudy-1}

Shell (strombus gigas) from disturbed upper zone of deposit, Trench 1. Comment (R.P.B.): in disturbed zone so that cultural identification not demonstrable, but it obviously applies to earlier phase at site, i.e., pre-Suazey complex. See RL-31. 
RL-31. Giraudy-2

Shell (strombus costatus) from lower undisturbed part of deposit, Trench 1. Comment (R.P.B.): dates earlier occupation of site with a late Modified Saladoid or early Terminal Saladoid ceramic inventory. Is comfortably $100 \mathrm{yr}$ earlier than RL-30 which was from a higher zone of the same trench.

\section{REFERENCES}

Broccker, W. S. and Farrand, W. R., 1963, Radiocarbon age of the Two Creeks forest bed, Wisconsin: Geol. Soc. America Bull., v. 74, p. 795-802.

Bullen, A. K. and Bullen, R. P., 1970, The Lavoutte Site, St. Lucia: 3rd internatl. cong. for the study of the Pre-Columbian cultures of the Lesser Antilles, Proc., St. George's, Grenada, 1969, p. 45-86.

Bullen, R. P., 1958, Stratigraphic tests at Bluffton, Volusia County, Florida: The Florida Anthropologist, v. 8, no. 1, p. 1-16.

Östlund, H. G. and Engstrand, L. G., 1963, Stockholm natural radiocarbon measurements V: Radiocarbon, v. 5, p. 203-227. 